\title{
A szervezeti belső kommunikációt gátló tényezők
}

\author{
M.CSÜLLÖG ${ }^{1}$, K. A. VÁRÓ², A. MATKÓ ${ }^{3}$ \\ ${ }^{1}$ Debreceni Egyetem, Műszaki Kar, mcsullog@lib.unideb.hu \\ 2Debreceni Egyetem, Múszaki Kar, varokata@eng.unideb.hu \\ ${ }^{3}$ Debreceni Egyetem, Mǔszaki Kar, andim@eng.unideb.hu
}

Absztrakt: Kutatásunkban arra kerestük a választ, hogy a választott szervezet dolgozói mennyire tartják fontosnak a szervezeti belső kommunikációt, milyen gátló tényezők akadályozzák annak hatékony múködését.

\section{Bevezetés}

Bármely szervezet információcseréjében előfordulhat az a helyzet, hogy bár léteznek a megfelelő kommunikációs csatornák és feltételek, mégsem lehet hatékony és sikeres belső szervezeti kommunikációról beszélni. Az alkalmazottak rendre felteszik kérdéseiket, közlik javaslataikat, választ mégsem kapnak, a vezető többször is közli a teendőket, még sincs foganatja, vagy épp a vezetőség folyamatosan kommunikálja a szervezet működését, fejlődését, az elért eredményeket, a dolgozók ennek ellenére csak a folyosói pletykáknak, a büfében elhangzottaknak hisznek, és azt tartják hiteles forrásnak (Papp, 2005:37-42).

Számos intézmény és szervezet elköveti azt a hibát, hogy csak a környezetük felé mutatják előnyös arcukat, csak a külvilággal tartják a kapcsolatot és fogalmaznak meg olyan üzeneteket, melyek pozitív képet alakítanak ki arculatukról, de nem szabad figyelmen kívül hagyniuk a belső kommunikációjuk megfelelő szinten tartását sem. A belső kommunikáció, a kapcsolatok kiépítése és ápolása fontos, mert amellett hogy hozzájárul a szervezet erősítéséhez, a külvilágra is pozitív hatást gyakorol a szervezet megítélésénél. A szervezet dolgozói életük nagy részét a szervezeten belül töltik, és mivel a kommunikáció emberi alapszükséglet, így annak figyelmen kívül hagyása bármely vállalat számára működési zavarokat okozhat. Ezen problémákat a kommunikációt gátló tényezők okozzák, melyek részletesebb ismertetését a szakirodalom és az elvégzett vizsgálatunk részeredményeinek tükrében kívánjuk bemutatni.

\section{A szervezet és a kommunikáció}

A szervezet egymással más-más mértékben, de összefüggő pozíciók közti viszonyokkal meghatározható társas struktúra, melyben az egyes pozíciókhoz tartozó egyéneknek a pozíció által többé vagy kevésbé világosan definiált társas szerepet kell eljátszaniuk (Rosengren, 2004:127).

A kommunikáció jelentőségét hangsúlyozva a szervezet fogalma Nagy József (1974) meghatározása szerint „a szervezet úgy definiálható, mint egy - legalábbis részben - önszabályozó rendszer, amelynek 
legfőbb sajátossága, hogy elemei közt ott találjuk az embert, aki eszközeivel együtt alkotja azt a szervezett egységet, amelyből a szervezett rend kialakítható. Egy huzalokból, telefonkészülékekből és kapcsolóközpontokból álló rendszer nem tekinthető szervezetnek, de azzá válik, ha megjelennek benne azok az emberek, akik ezt a kommunikációs rendszert múködtetik".

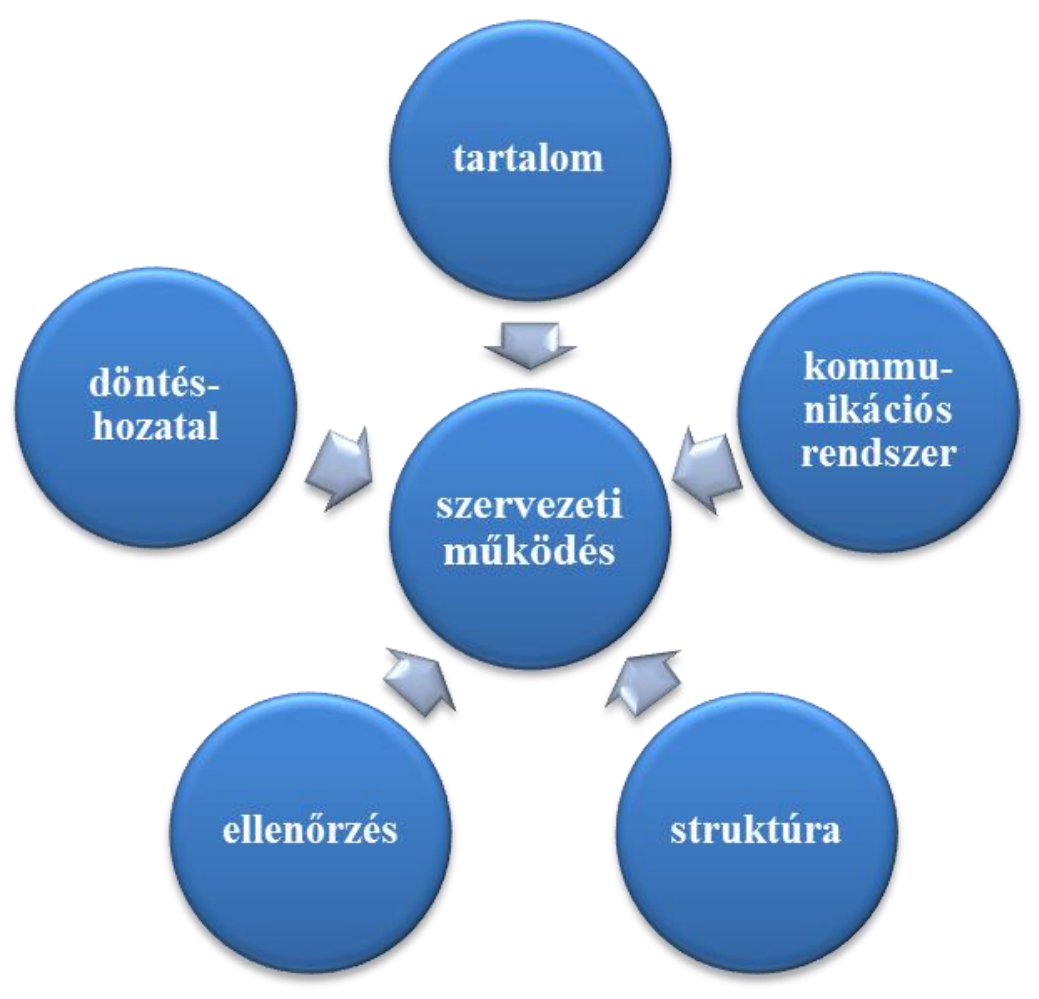

1. ábra: A szervezet múködését befolyásoló tényezők

A szervezet működését alapvetően 5 tényező befolyásolja (3. ábra):

1. A tartalom: a szervezet rendelkezésére álló erőforrások, legyen az humán, eszköz vagy anyagi.

2. A struktúra: a szervezet különböző funkcióinak, tevékenységeinek kapcsolati rendszere.

3. A kommunikációs rendszer: a szervezet működését csak megfelelő, jól működő kommunikációs rendszer biztosíthatja, amely lehetővé teszi, hogy a megfelelő információ a megfelelő helyen, a megfelelő időben, és a megfelelő jelentéstartalommal álljon rendelkezésre. Szervezetről is csak akkor lehet szó, ha az emberekből álló csoport, csoportok közvetlenül vagy közvetve hatnak egymásra.

4. Az ellenőrzés: a szervezet nem létezhet anélkül, hogy időről-időre felül ne vizsgálná működését és ne ellenőrizné, hogy jó úton jár-e a kitűzött cél elérésére.

5. A döntéshozatal: lehet egy szervezetnek kiváló személyzete, struktúrája, kommunikációja és ellenőrzési rendszere, de a munkája nem lesz eredményes, ha nincs egy jól működő döntési mechanizmusa (Johnson, 1971:289-295). 


\subsection{A szervezeti belső kommunikáció}

A kommunikáció alapvető összetevője a szervezeteknek, a munkaidő csaknem 95\%-át információcsere tölti ki, és ennek csökkenése a jövőben sem várható (Mikulás, 1999:207).

A szervezet vezetői rendszerint munkaidejük nagy részét menedzsment feladatokkal, azon belül is kommunikációval töltik. Mintzberg (1975) szerint a vezetők idejük túlnyomó többségét kommunikálásra fordítják, legyen az üzenetek, jelentések olvasása és írása vagy részvétel megbeszéléseken, értekezleteken. Ugyanakkor egyre több alkalmazott is hasonló helyzetbe kerül, a munkája fontos részévé vált/válik a kommunikáció.

A szervezeti kommunikáció fogalma nem csupán a gazdálkodó szervezetekben és az azokkal folytatott kommunikációt fedi, hanem valamennyi, a szervezet ismérveivel (tudatos, közös célorientáltság, a célmegvalósítás érdekében működtetett racionalitás, körülhatárolható számú tag, belső szerepdifferenciálódás, a tagok között fennálló emberi viszonyok, közös identitástudat) jellemezhető szociális képződményt is (Borgulya, 2010).

A szervezeti belső kommunikációnak négy alapvető funkciót kell ellátnia:

- érzelmi: a kommunikációval a szervezet tagjai kifejezésre juttatják érzelmeiket, elégedettségüket;

- motivációs: a különböző motivációs eszközökkel (dicséret, meggyőzés) a munkatársak bátoríthatják, ösztönözhetik egymást;

- információs: bizonytalanságot szüntet meg, segíti a döntéshozatalt, fontos a megfelelő mértékű és pontosságú információ rendelkezésre állása;

- ellenőrzési: a munkatársak visszajelzést kaphatnak a kommunikáció által a szervezetben folyó tevékenységekről, és saját tevékenységükről (Dajnoki, 2003:248).

„A szervezeten belüli kommunikáció olyan egy vagy kétirányú közlési folyamat, mely akár élő szóban akár írásos formában információáramlást jelent a vállalati stratégiával, változásokkal és a hétköznapi folyamatokkal kapcsolatosan" (Nagypál, 2009), amely a közös cél érdekében végzett munka tervezését, irányítását, ellenőrzését, értékelését, a működési feltételek biztosítását, az erőforrások összehangolását teszi lehetővé. Közvetíti az értékeket, a normákat, a szervezeti kultúrát, fontos szerepet játszik a hatalmi struktúrák működésében, a szervezeti szerepek betöltésében, a munkahelyi légkör alakításában, valamint a munkahelyi konfliktusok kialakulásában, kezelésében és megoldásában (Karoliny, 2010:409). "Célja olyan kölcsönösen előnyös kapcsolat létrehozása és fenntartása a szervezet menedzsmentje és alkalmazottjai között, amelytől a szervezet léte és sikeres működése függ"(Nyárádi, 2002:15-19).

A belső kommunikációnak központi szerepet kell betöltenie a szervezetek életében, segítségével koordinálható a tagok mindennapi feladatvégzése, motiválható bizonyos tevékenységek elvégzése és befolyásolható a szervezethez tartozók magatartása is.

\subsection{A belső szervezeti kommunikációs akadályok}

A kommunikáció négy funkciója közül az információs szerepnek kitüntetett rendeltetése van az intézmények életében. Az információ biztosítja a vezetők és vezetettek tájékozódását. Ennek 
teljesülésében komoly szerepe van az adatok teljességének és pontosságának, valamint a közvetítő csatorna kellő mértékű fenntartásának.

Az információ értékét hasznossága, alkalmazhatósága adja, alapkövetelmény, hogy a folyamatokat objektíven, a valóságnak megfelelően tükrözze, azaz az információ:

- reális, hiteles, megbízható, igazodik a döntési szintekhez;

- időben gyors és friss adatokat szolgáltat;

- a legfontosabbakat foglalja magába;

- áramlása folyamatos és sokoldalú (Semeginé, 2013:25).

Ideális esetben a leírtaknak kellene teljesülnie, de a kommunikáció során „törvényszerűen” torzulás, információvesztés következik be, amit a szervezeti belső kommunikációt akadályozó tényezők váltanak ki.

A belső információcserében a kommunikációs gátakat három fő csoportba lehet sorolni, e szerint lehet beszélni fizikai, szemantikai és szociálpszichológiai akadályokról.

\section{Szemantikai}

A szemantikai értelmezési problémák elsősorban a kommunikáció során használt jelrendszer nem azonos ismeretéből származnak. Fontos ugyanis, hogy a szervezeti célok elérésében a különböző információ felvételi, illetve kibocsátási pontokon az információt azonosan értelmezzék (Klein, 2011:431), ennek hiányában zavar lép fel.

\section{Fizikai}

A fizikai akadályokon a nemkívánatos zaj értendő, például csöngő telefon, tárgyalás közben zavarkodó kollégák. A szervezetek életében ezen kívül azonban még számos, ebbe a csoportba sorolható gátló tényező fordulhat elő.

Elsőként a nem megfelelő infrastruktúra, ugyanis a megfelelő technikai eszközök nélkül aligha teljesülhet a hatékony kommunikáció megvalósulása.

A szervezeten belüli távolság, amely csökkenti a személyes kommunikáció gyakoriságát. A személyes kommunikáció a leghatékonyabb forma, mivel ha nem csak halljuk, hanem látjuk is a kommunikációs partnert, tisztább képet kapunk, hogy pontosan megértette a közölteket, avagy nem.

A szervezet felépítése: minél hierarchikusabb egy szervezet, annál inkább valószínű, hogy a szervezeti belső kommunikáció kevésbé működik hatékonyan, továbbá előfordulhat, hogy bizonyos információk egyes szervezeti szintek monopóliumaként kezeltetnek. Rendszerint előfordul, hogy az alacsonyabb szinten lévő a véleményében hasonul a felette állóéhoz (ezredes hatás), az ún. kemény információk blokkolásra kerülnek, vagy információs dömping jelenik meg (Bakacsi, 2002:144).

A rossz időzítés haragot, érdektelenséget és bizalomvesztést okozhat. Tudni kell, hogy mikor kell információt közölni. 
Minél hosszabb az átviteli csatorna, minél több az áttétel, annál inkább akadozóvá válik az információ áramlása, könnyebben módosul akaratlanul vagy szándékosan (Mikulás,1999:210).

Rosszul megválasztott csatorna. Előfordulhat, hogy a vállalatvezetés csak e-mailben kíván kommunikálni, miközben a beosztottak jobban preferálnák a személyes információcserét és annak hiánya a hiányérzetet, ezen keresztül pedig elégedetlenséget vált ki a dolgozókból (Borgulya, 2010: 231).

A vezetôségi szintek száma, ugyanis a vezetési szinteken lefelé haladó információ leszűkül, torzul.

A szervezet alul- vagy túlszabályozottsága. Ha nincsenek egyértelműen definiálva a kommunikációs utak, felelősségi-, jog- és hatáskörök, vagy túl merev a szervezet koordinálása, akkor zavar jelentkezik az információcserében.

A vállalati méret. Az alkalmazottak számának gyarapodásával növekszik a kommunikáció mennyisége, de ezzel párhuzamosan csökken a személyesség mértéke is. A szervezeti kultúra erőteljes formalizálódásával a vállalaton belüli kommunikációban is a formális tájékozódás válik túlsúlyossá. A vállalat legalsó fokán az alkalmazottak már nem kapnak teljes mérvű felvilágosítást (erre minden esetben nincs is szükség, például vállalati titkokat nem oszt meg a vezetőség minden alkalmazottal) a döntések meghozataláról, megszületéséről (Semeginé, 2009:103-112).

A csoportmunkában a csoport tagjainak a száma. Az ideális az 5-9 fő, ennél több esetén valószínűsíthető az eredményesség csökkenése, a csoport kevésbé hatékonyan tud együttműködni a különböző feladatok megoldásában. Nem véletlenül a vállalati stratégia megtervezésénél is maximum 4-6 fő (jellemzően a vezetők) vesz részt.

Túl kevés vagy túl sok információ közlése. A túl kevés információ érdektelenséget, vagy aggodalmat válthat ki, míg a túl sok hatására nagy lesz az irreleváns információk halmaza, az üzenetekkel terhelt kommunikációs rendszert a fogadó figyelmen kívül hagyja és ezáltal lényeges információk kerülhetik el a címzett figyelmét.

\section{Szociálpszichológiai}

Az egyén érzelmi állapota, a kommunikációs partnerről szerzett előzetes tudás, a kölcsönös bizalom, megértés és érzelmi kötődés vagy ezek hiánya nagymértékben befolyásolja a kommunikáció sikerességét. Jellemző, hogy az ember nem mindig adja át ugyanazt az információt ugyanúgy két különböző kommunikációs partnernek.

Az alkalmazottak a szervezeten belül más-más kapcsolatrendszerbe épülnek be, ezzel befolyásolva, hogy ki-kivel és hogyan kommunikál. Előfordulhat, hogy ha valakit jobban, ha valakit kevésbé kedvel, vagy ki akarja közösíteni az adott szűk kommunikációs háló tagjainak többsége, akkor annak tagjai egyéni szinten is törekedni fognak annak megvalósítására.

Az érdeklődés mértéke alapjaiban határozza meg, hogy a fogadó személye milyen szinten fogadja be a közölteket, a pletykák is jobban terjednek, ha a terjesztőket közvetlenül érintő -magas érdekeltségi szintű - kérdésekről van szó (Higham, 1966). 
A túlzott motiváció befolyása alatt torzulhat az információ, a görcsös akarástól a fogadó személyében az üzenet tartalma új és más értelmezést nyerhet, mint az valójában volt.

A kollégákról szerzett előzetes tudás, mivel az emberek a hozzájuk érkező információt nem csak a tartalma alapján értékelik, hanem azt is figyelik, hogy honnan származik az adott információ. Ha a szervezet egy dolgozójáról a többi tudja, hogy az rendre valótlant állít, akkor a tőle érkező információt nem tartják hitelesnek és figyelmen kívül hagyják azt.

A szervezetek folyamatos mozgása, változik az emberek pozíciója, a csoportok összetétele, földrajzi elhelyezkedése és emiatt az üzenetek gyakran nem jutnak el a címzetthez (Klein,2001:441).

A vezetővel való széleskörü kommunikáció nélkül a vezetett nem tudhatja, hogy milyen az a helyzet, amelyhez alkalmazkodnia kell, hogyan kell végeznie munkáját, mikor látja el jól feladatait. A megfelelő kommunikáció nélkül bizonytalanságban érzi magát a beosztott. Az alkalmazott felőli kommunikáció is legalább ilyen fontos, mivel a vezető ez alapján ismeri meg dolgozóit, határozza meg, hogy kinek milyen feladatot kell ellátni, tudja eldönteti, hogy az egyes beosztottak felé milyen elvárásai lehetnek (Klein, 2001:416).

A bizalmi viszony a vezető és beosztott között, ugyanis a két fél kapcsolata és kommunikációja alapvetően határozza meg az egész szervezet működését, hatékonyságát, teljesítményét, a vállalat jövedelmezőségét (Tracy, 2014:12).

A túl hosszú közlés vagy a párhuzamos tájékoztatás unalmassá válik.

Az egyén szándékosan torzít, például a vezetője felé jobb színben tünteti fel saját munkáját, mint amilyen az valójában (Semeginé, 2013:26).

Helytelen konfliktuskommunikáció. Sem a vezető, sem a beosztott nem rendelkezik azzal az eszköztárral, amely segíthetné a problémák megoldását.

Rossz kritikatürés. A cselekvésre, annak eredményére irányuló kritikát a szervezet dolgozói nehezen viselik, gyakorta személyüket érő támadásként értelmezik.

Irigység. Ha az alkalmazottak között van olyan, aki úgy véli, hogy másvalaki kevesebb erőfeszítés árán jut előbbre a munkahelyen, akkor a munkatársak között ellenséges magatartás alakulhat ki.

A kulturális különbségek. Az eltérő nyelv, a szociokulturális vagy épp pszichokulturális tényezők zavarkeltőek lehetnek (Borgulya, 2010:236-240).

\subsection{A rosszul működő szervezeti belső kommunikáció következményei}

Minden szervezet emberek csoportját fogja össze, melyben a kommunikáció kulcsfontosságú eszköz a szervezet hatékony működésének eléréséhez. A nem megfelelő kommunikáció a teljesítményt negatívan befolyásolja, ezzel veszélyeztetve a szervezet működését, céljainak elérését és küldetésének beteljesítését. A kommunikáció produktivitása alapvető az egyén és a szervezet készségeinek, képességeinek maximális szintre történő fejlesztésében, annak nem megfelelő kihasználása, legyen az formális vagy informális kommunikáció, egyenes út a motiváció elvesztése és a teljesítmény 
csökkenése felé. A rossz kommunikáció idő- és pénzpazarlás mellett termékeny talaja a munkahelyi súrlódások és konfliktusok kialakulásának. Jellemző, hogy az ilyen szervezetekben:

- a szervezet tagjai nem tudják, milyen feladatokat kell ellátniuk, ésszerűtlen a munkavégzés, a munkaszervezés;

- a dolgozók nincsenek tisztában a nehézségek okaival, ami az erőforrások pocséklását is okozza;

- a félreértések, összetűzések rossz munkakapcsolatot, munkalégkört eredményeznek;

- az alkalmazott nem osztja meg ötleteit, elképzeléseit, nem adja át tapasztalatát, ami visszafogja a készségek fejlődését, az új dolgozók beilleszkedésének sikerességét;

- a szervezet beosztottjai nem tudják mi a célja, az értelme az elvégzett munkájuknak;

- csökken a munkamorál, nagy a munkahelyi fluktuáció;

- a szervezet múködése rugalmatlan lesz, lassú válaszokat ad a környezeti változásokra;

- a vállalat rossz hírnévre tesz szert a vevők, ügyfelek, partnerek, beszállítók körében (Roebuck, 2000:11).

\section{A kutatás}

\section{A kutatás célja}

Kutatásunk során arra kerestük a választ, hogy az alkalmazottak mennyire tartják fontosnak a szervezeti belső kommunikációt és milyen gátló tényezők akadályozzák a vizsgált intézményben annak hatékony működését. Tanulmányoztuk, hogy vajon egy szervezetileg erősen tagolt, és részben térben is elszigetelt egységekből álló intézményben milyen különbségek, azonosságok mutatkoznak a belső kommunikációt gátló tényezők vizsgálatakor a választott szervezet egyes egységeiben, illetve a szervezetben van-e kimutatható tendencia közöttük.

Az elvégzett vizsgálat alkalmazott kutatás, ugyanis már meglévő kutatásokat felhasználva, azokból kiindulva folytattuk le a vizsgálatot, és tártunk fel új és újszerű ismereteket (Fóris, 2008: 43).

Jelen tanulmány egy átfogó felmérés részeredményeit tartalmazza.

\section{A kutatás helyszíne}

A vizsgálatunkat egy nonprofit szervezet dolgozóinak körében folytattuk le.

A szervezet főbb ismérvei:

- dolgozói összlétszáma 120 fő;

- térben tagolt, egymástól távol elhelyezkedő több szervezeti egységgel rendelkezik;

- az egyes egységek dolgozói létszáma széles skálán mozog, van 2-3 fős és 42 fős részleg is;

- a szervezet mátrix struktúrájú és 5 hierarchikus szint különíthető el. Élén a főigazgató, alatta a főigazgató helyettesek, majd az egyes egységek vezetői, aztán következnek az osztályvezetők és a szervezet legalsó szintjén a különböző munkaköröket betöltő alkalmazottak állnak;

- a vezetői értekezleteken születnek a legfontosabb döntések, az egységvezetők közvetlenül részt vesznek a döntéshozatalban; 
- az egységek szakmai, munkahelyi kérdésekben bizottsági gyűléseken egyeztetnek, a bizottságok főképp javaslattételi jogkörrel rendelkeznek;

- a szervezet rendelkezik honlappal, belső levelezőrendszerrel, intranettel;

- nincs a kommunikációért felelős alkalmazott.

A szervezeti belső kommunikációs vizsgálat lefolytatására a választott intézményt megfelelőnek ítéltük, mert kellően tagolt, az egyes részlegek dolgozói létszáma jelentősen eltér egymástól, magas a hierarchiaszint, valamint a szervezetnek vannak térben távol elhelyezkedő szervezeti egységei is.

\section{A kutatás módszere}

A kutatást online kérdőíves kvantitatív felmérés formájában valósult meg, a mintába az összes alkalmazott bekerült. A szervezet tagjai e-mailben kaptak felkérést a kérdőív kitöltésére. Az anonimitás biztosítva volt azáltal, hogy a kitöltőknek nem kellett a nevüket megadni és online felületen lehetett a kitöltéseket megtenni. A felmérést 2014 októberében folytattuk le. A kérdőíveztetés ideje alatt a célcsoport további három alkalommal kapott felhívást a kérdőív kitöltésére. Az elkészített online kérdőívhez csak a szervezet dolgozói férhettek hozzá, ezzel biztosítva, hogy külső személyek ne torzítsanak az eredményen.

Az alkalmazott kérdőívet Semeginé dr. Tariszka Éva „Szervezeti belső kommunikáció rendszerének korszerű kialakítása"- című doktori értekezésében alkalmazta, így biztosítva volt annak alkalmazhatósága, hitelessége. Zárt és nyitott kérdéseket is tartalmazott a felmérés. A gátló tényezők és a szervezeti belső kommunikáció fontosságát megítélő kérdéseknél a válaszadók 1-5-ig terjedő Likert-skálán adhattak minősítést.

A mérés lezárásáig összesen 64 kitöltött kérdőív került visszaküldésre, tehát a megkérdezettek 53,33\%-a válaszolt.

Tekintve, hogy többféle csoportosítási szempontot is alkalmaztunk a minta kiértékelésénél, számításba vettük, hogy 100 fő alatt nincs különösebb értelme a százalékolásnak és 30 főnél pedig az átlag értékek számításának (Kabai, 2009), így az elemzésünk során túlnyomórészt átlag és szórásértékekkel reprezentáltuk a kapott eredményeket. A kapott átlagértékek között az 0,5-es különbséget vettük szignifikánsnak, vagyis jelentős mértékű eltérésnek. 


\subsection{A belső kommunikáció fontosságának megítélése}

\begin{tabular}{|l|r|r|}
\hline & Átlag & Szórás \\
\hline munkatársak közérzetét & 4,19 & 0,774 \\
\hline vezető-beosztott közötti viszonyt & 4,20 & 0,717 \\
\hline szervezeti egységek egymáshoz való viszonyát & 4,19 & 0,710 \\
\hline bizalom-bizalmatlanság légkörének kialakulását & 4,38 & 0,807 \\
\hline szervezeten belüli konfliktusok kialakulását & 4,08 & 0,783 \\
\hline vezetés döntéshozatali mechanizmusát & 3,61 & 0,953 \\
\hline feladatok pontos értelmezését és végrehajtását & 4,28 & 0,845 \\
\hline szervezeti múködés hatékonyságát & 4,23 & 0,831 \\
\hline szervezeti kultúrát és etikát & 4,13 & 0,917 \\
\hline
\end{tabular}

1. táblázat: A belső kommunikáció által befolyásolt tényezők fontossága a válaszadók szerint

Az elvégzett vizsgálatról a választott intézmény egészét tekintve, a kapott válaszok átlagértékei alapján általánosan megállapítható, hogy az alkalmazottak úgy gondolják, a szervezeti belső kommunikáció nagy hatással van (1. táblázat) a munkahely légkörére $(4,19)$, a vezető-vezetett közötti kapcsolatra $(4,20)$, az egységek egymás közötti viszonyára $(4,19)$, a bizalom-bizalmatlanság légkörének alakulására $(4,38)$, a konfliktusok generálódására $(4,08)$. Ugyanígy fontosnak tartják a feladatok pontos értelmezésében $(4,28)$, a szervezet működési hatékonyságában $(4,23)$ és a szervezeti kultúra, a közös értékek közvetítésében $(4,13)$. Mindez pedig egyértelműen megerősíti (a szakirodalmat is alátámasztva), hogy a szervezeti belső kommunikációnak nagyon fontos szerepe van a szervezetek megfelelő és hatékony működésében. 


\subsubsection{A szervezeti egységek véleménye a belső kommunikáció fontosságáról.}

Érdekes tendencia mutatkozott, amikor az egyes szervezeti egységek véleményeit hasonlítottuk össze az elemzett tényezőkre vonatkozóan.

\begin{tabular}{|c|c|c|c|c|c|c|c|c|c|}
\hline \multirow{3}{*}{$\begin{array}{l}\text { Egysége } \\
\text { dolgozó } \\
\text { létszám } \\
\text { szerint }\end{array}$} & \multicolumn{9}{|c|}{ A belső kommunikáció milyen mértékben befolyásolja a(z) } \\
\hline & 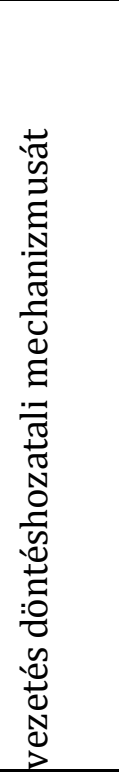 & 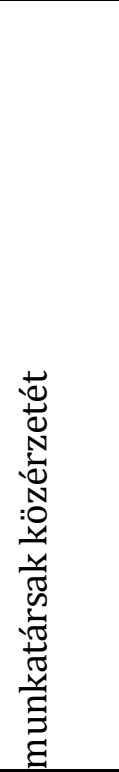 & \begin{tabular}{l}
\multicolumn{2}{c}{} \\
0 \\
0 \\
$N$ \\
0 \\
0 \\
0 \\
0 \\
0 \\
0 \\
0 \\
0 \\
0 \\
0 \\
0 \\
0 \\
0 \\
0 \\
0 \\
0 \\
0 \\
0 \\
0 \\
0 \\
0
\end{tabular} & 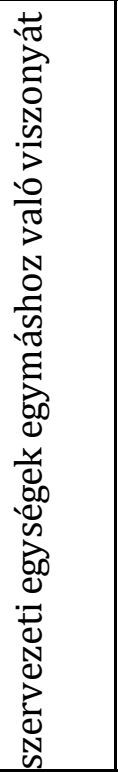 & 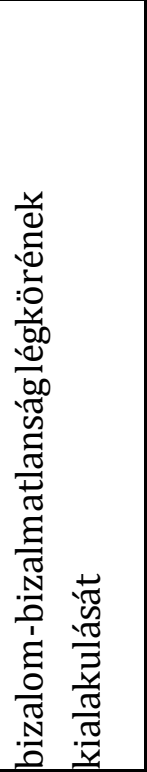 & 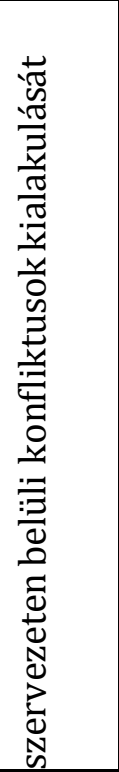 & 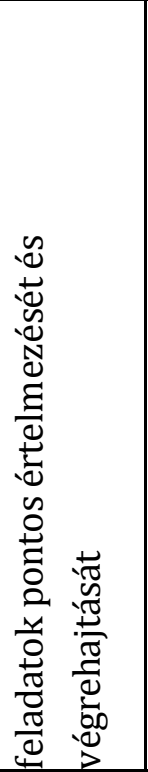 & 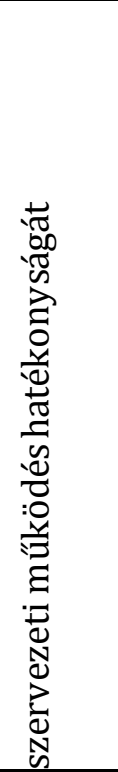 & 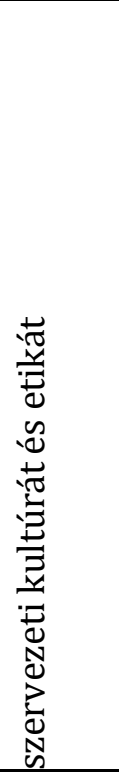 \\
\hline & \multicolumn{9}{|c|}{ Átlagértékek } \\
\hline 1-3 & 4,5 & 4,67 & 4,67 & 4,5 & 4,83 & 4,83 & 4,83 & 4,67 & 4,17 \\
\hline $4-8$ & 3,86 & 4 & 4,14 & 4 & 4,29 & 4 & 4 & 4,43 & 4,29 \\
\hline $9-12$ & 3,5 & 4 & 4 & 4 & 4,25 & 3,83 & 4 & 4 & 4,33 \\
\hline $\begin{array}{l}\text { 15-nél } \\
\text { több }\end{array}$ & 3,46 & 4,21 & 4,21 & 4,23 & 4,36 & 4,05 & 4,23 & 4,28 & 4,03 \\
\hline
\end{tabular}

2. táblázat: A szervezeti belsó kommunikáció fontosságának megítélése szervezeti egységenként

A legkisebb (1-3 fős) szervezeti egységek dolgozói tartják szinte minden vizsgált tény ező esetén (a szervezeti kultúra és etika közvetítését illetően hasonló véleményen vannak az egyes egységek) a legfontosabbnak az intern kommunikációt (2. táblázat) (több válaszlehetőségnél jelentős különbség mutatkozott a többi egységhez viszonyítva). Jellemzően ezek az egységek helyezkednek el legtávolabb a szervezet központjától és a többi szervezeti egységtől, így csaknem természetszerű, hogy a szervezet egészének produktív működése érdekében nagyon fontosnak tartják a belső kommunikáció megfelelő funkcionálását.

\subsubsection{A vezetés döntéshozatalára gyakorolt hatás}

A szervezet dolgozóinak bevonása a döntéshozatalba rendkívül fontos, ugyanis ha a vezető például pontosan megbeszéli beosztottjával, hogy milyen feladatot kell ellátnia és milyen módszert kell erre alkalmaznia, akkor az alkalmazott nagyobb valószínűséggel fogja az elvégzendő munkát sajátjának érezni, ezzel pedig várhatóan a dolgozó sokkal jobb minőséget fog produkálni, ami növeli a saját elégedettségét és a szervezet működési hatékonyságát (Tracy, 2014:53). 
A vizsgált intézménynél a szervezeti belső kommunikáció a vezetés döntéshozatali mechanizmusára gyakorolt hatását a válaszadók összességében csak kevésbé érezték jelentősnek (3,61-os átlag), ami a szervezet sikerességét negatívan befolyásolhatja. Árnyaltabb képet kaptunk, amikor az egyes egységek véleményét hasonlítottuk össze (2. ábra). Kiderült részben, hogy az 1-3 fős egységekben szignifikáns különbség mutatkozik a többi egységhez viszonyítva, ugyanakkor az is kirajzolódott, hogy a kevesebb dolgozóval rendelkező szervezeti egységekben (az 1-3 fôs és a 4-8 fős egységeket sorolom ide) úgy tapasztalják, hogy erőteljes hatása van a belső kommunikációnak (annak segítségével jobban tudják érvényesíteni elképzeléseiket, akaratukat) a vezetői döntéshozatalra, míg a nagyobbak ezt kevésbé érzékelik.

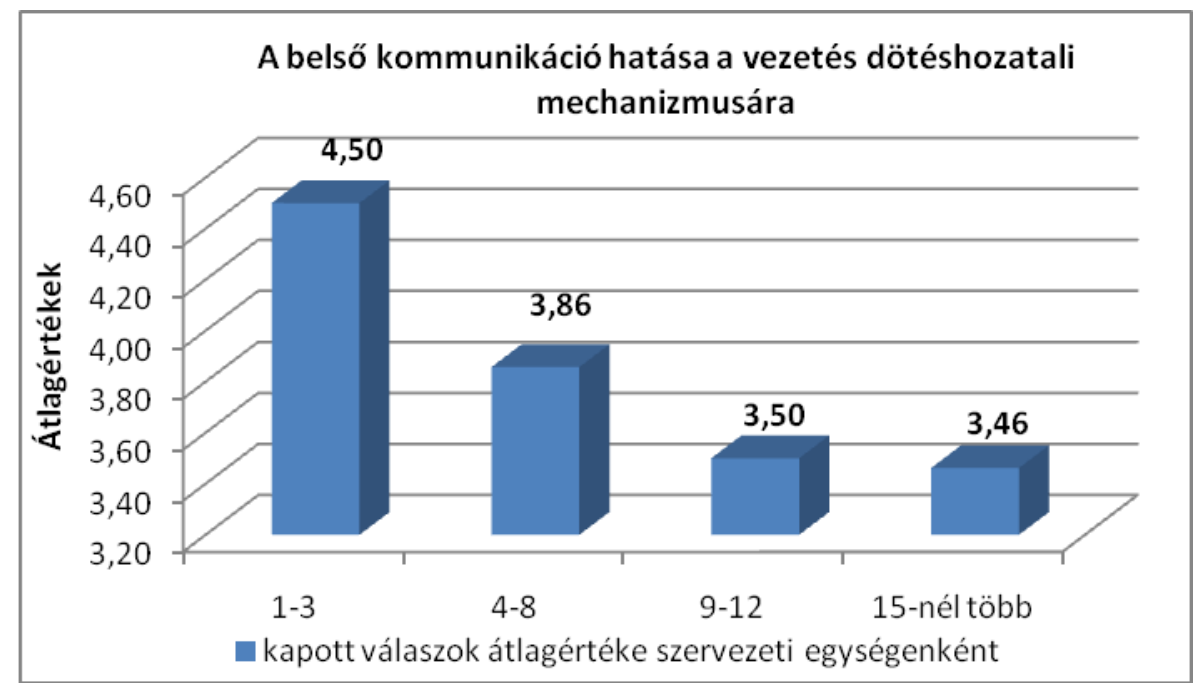

2. ábra: A szervezeti belső kommunikáció hatása a vezetés döntéshozatali mechanizmusára szervezeti egységenkénti bontásban

Ennek magyarázata az egyes egységek létszámbeli különbsége és a szervezet magas strukturális felépítése. A döntések a vezetői értekezleteken születnek, ahol a kis egységek vezetői is részt vesznek (ugyanis tagok a legfőbb döntéshozó szervben, a vezetői tanácsban). Így ők és a közvetlen beosztottjaik nem érzékelik a magas szervezeti struktúra hátrányát (az egységvezető is aktív részese a döntéshozatalnak, így a beosztott számos kérdésben a 3. szintre kerülhet, köszönhetően a szoros napi munkakapcsolatnak). Ezzel szemben a nagyobb egységek beosztottjai úgy értékelik, hogy a szervezeti belső kommunikációnak nem lehet jelentősebb hatása erre a területre. Például a nagyobb egységek alkalmazottai, ha a munkájuk szempontjából fontos döntéseket akarják befolyásolni (kivel akarnak dolgozni, milyen eszközökre van szükségük és így tovább) feltételezhetően nem fordulhatnak rögtön az adott egységvezetőhöz, hanem a szolgálati utat figyelembe véve (csoportvezető, osztályvezető és csak ezután az egységvezető) tudja csak kifejezni akaratát, amely a vizsgált intézménynél több alkalmazott esetén is akár 3-4 szervezeti szintet is jelenthet. Ugyanakkor minél több dolgozó van egy adott egységben, annál kevesebb idő jut az egységvezetőnek az egyes beosztottjaira, ezáltal a vezetett is kevésbé érezheti úgy, hogy jelentős befolyást gyakorolhat a vezetői döntéshozatalra. 


\subsection{A szervezeti belső kommunikációs akadályok}

\begin{tabular}{|l|r|r|r|r|r|r|}
\hline & $1-3$ & $4-8$ & $9-12$ & 15-nél több & $\begin{array}{r}\text { A teljes } \\
\text { szervezet }\end{array}$ & Szórás \\
\hline Rossz munkahelyi légkör & 1,67 & 2,00 & 1,36 & 1,85 & 1,80 & 1,011 \\
\hline A vezető nem tájékoztat időben & 1,50 & 2,33 & 2,18 & 2,50 & 2,34 & 1,185 \\
\hline Térbeli elszigeteltség & 2,50 & 2,50 & 1,55 & 2,06 & 2,05 & 1,174 \\
\hline Munkatársak közötti konfliktus & 1,83 & 2,33 & 1,45 & 2,06 & 1,92 & 1,074 \\
\hline Nem tervszerű kommunikáció & 2,33 & 2,50 & 2,27 & 2,71 & 2,63 & 1,241 \\
\hline Együttműködés, csapatmunka hiánya & 1,83 & 2,17 & 1,82 & 2,79 & 2,50 & 1,247 \\
\hline Vezetői döntések & 2,00 & 2,17 & 2,55 & 2,68 & 2,53 & 1,272 \\
\hline $\begin{array}{l}\text { Vezető és beosztott közötti } \\
\text { bizalmatlanság }\end{array}$ & 2,67 & 3,14 & 2,92 & 2,79 & 3,31 & 1,258 \\
\hline $\begin{array}{l}\text { Az információszerzést bizalmatlanság } \\
\text { nehezíti }\end{array}$ & 2,67 & 3,4 & 3,18 & 2,88 & 3,00 & 0,976 \\
\hline
\end{tabular}

3. táblázat: A hatékony kommunikációt gátló tényezők egységenként és a teljes szervezetre vetítve

A rossz munkahelyi légkör az összes alkalmazott véleményét figyelembe véve, alacsony szórás mellett $(1,011)$ alacsony átlagértéket $(1,80)$ kapott $(3$. táblázat), amely jelzi, hogy az intézményben jobbára kiegyensúlyozott az légkör.

A saját egységen belüli kommunikációt gátló tényezők közül a teljes szervezetre vetítve a kapott eredményeket a nem tervszerű kommunikációt $(2,63)$, a vezető és beosztott közötti bizalmatlanságot $(3,31)$ és az információszerzést akadályozó bizalmatlanságot $(3,00)$ minősítették a legfontosabb gátló tényezőknek. Fontos megjegyezni, hogy több vizsgált akadályozó paraméternél magas szórásértéket kaptunk, ami jelzi, hogy az egyén szintjén más-más mértékű a kommunikációt gátló tényezők érzékelése. Van olyan alkalmazott, aki az adott gátló tényezőt súlyosabbnak, míg más kevésbé jelentősnek tartja.

Ki kell emelni továbbá, hogy a térbeli elszigeteltség a legtávolabb elhelyezkedő részekben jelent problémát (1-3 és 4-8 fôs egységek). A csapatmunka és az együttműködés hiánya a legnagyobb szervezeti egységekben a jelentősebb hátráltató tényező, amihez párosul, hogy a nem tervszerű kommunikáció hiányát is ők minősítették fontosabbnak, éppen ott, ahol a dolgozói létszámból adódóan erőteljesebben felértékelődik az információcsere a munkavégzés egységen belüli optimális összehangolásakor. Nyilvánvaló, hogy a kevesebb alkalmazottal rendelkező egységek saját egységen belül könnyebben megszervezik a közös munkavégzésüket, és így kevésbé jelent számukra akadályt a nem megfelelő szervezésű kommunikáció. 


\subsubsection{Bizalom és döntés}

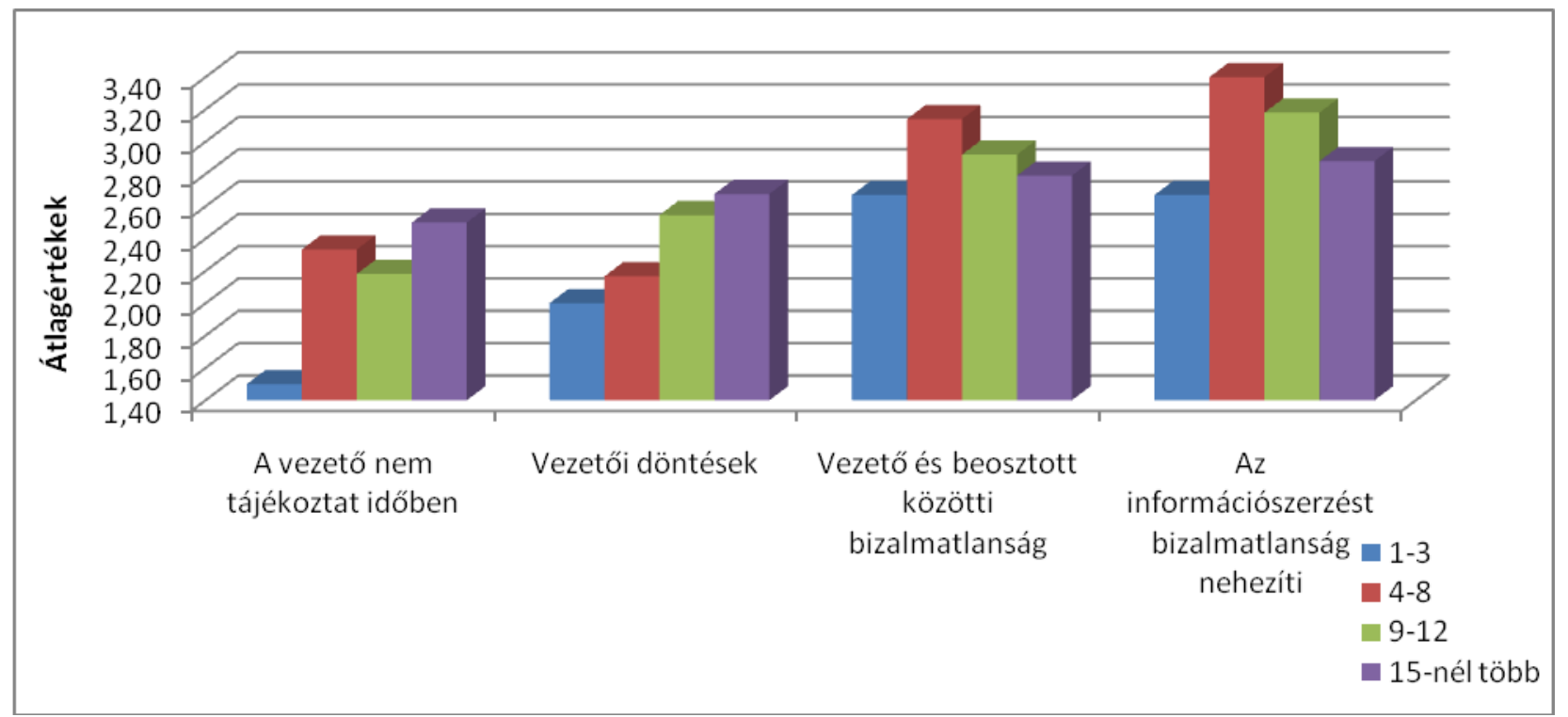

3. ábra: A vezető és beosztott közötti bizalom és a vezetői döntések közötti összefüggés szervezeti egységenkénti bontásban

A kapott eredmények alapján megállapítható, ha a vezető és az irányított személyek kapcsolata negatív, akkor az az elvégzett munka mértékének és a teljesítmény minőségének rovására mehet. A rossz viszony a beosztottban félelmet, ellenállást válthat ki, és úgy érezheti a vezetett, hogy felesleges a vezetőjével érdemben kommunikálni, mivel az úgy sem fogja elfogadni, befogadni elképzeléseit, ötleteit.

A vezetők felől érkező tájékoztatás késedelmességét a kis szervezeti egységek kevésbé érzik gátló tényezőnek (3. ábra és 3. táblázat). Kétségtelen, hogy ahol 2-3 ember végzi a munkáját, ott az egységvezetőnek is szorosabban együtt kell működnie a közvetlen munkatársával, beosztottjával. A mindennapos szorosabb munkakapcsolat bizalmasabb viszonyt is feltételez, ahogyan ez a kapott eredményekből is kitűnik (3. ábra és 3. táblázat). Az 1-3 fős egységekben kevésbé akadályozza a kommunikációt bizalmatlanság és a vezető és a beosztott között is bizalmasabb viszony áll fent, ami nyilvánvalóan közrejátszik a vezetői döntések beosztottak általi könnyebb elfogadásához, mivel ahogy látható a vezetői döntések is a legkisebb szervezeti egységekben jelentenek alacsonyabb szintű kommunikációt akadályozó tényezőt, megerősítve hogy az alkalmazottak az 1-3 fős egységekben tartották legerősebbnek a szervezeti belső kommunikáció hatását a vezetői döntéshozatalra (2. ábra). 


\subsubsection{Szervezeti egységek közötti kommunikációt gátló tényezők}

A szervezeti egységek egymás közötti kapcsolattartásában nagyon fontosnak érzik a dolgozók (1. táblázat) az intern kommunikációt.

\begin{tabular}{|l|r|r|}
\hline & Átlag & Szórás \\
\hline Nincs személyes kontaktus & 3,16 & 1,224 \\
\hline Rossz személyes kontaktus & 2,91 & 1,354 \\
\hline Rossz technikai feltételek & 2,45 & 1,344 \\
\hline Nagy térbeli távolság & 2,64 & 1,289 \\
\hline Vezetők közötti rivalizálás & 2,78 & 1,266 \\
\hline Hosszú az információs csatorna & 3,17 & 1,062 \\
\hline Torzulnak az információk & 3,31 & 1,125 \\
\hline Információt tartanak vissza & 2,86 & 1,344 \\
\hline Érdektelenség/motiváció hiánya & 3,47 & 1,391 \\
\hline
\end{tabular}

4. táblázat: A hatékony kommunikációt gátló tényezők az egységek között

A vizsgált szervezet dolgozói a szervezeti egységek közötti kommunikációban a legfontosabb gátló tényezőként (4. táblázat) az érdektelenséget (3,47-os átlagérték), a vezető és beosztott közötti rossz viszonyt $(3,31)$, az információk torzulását $(3,31)$, a hosszú információs csatornát $(3,17)$ és a személyes kommunikáció $(3,16)$ hiányát jelölték meg. Magyarázza ezt a szervezet tagoltsága, a szervezeti hierarchia öt szintjéből eredeztethető magas szervezeti struktúra, a szemtől szembeni információcsere népszerűsége (vizsgálatunk alapján a 90,63 \%, 5. ábra), valamint, hogy az érdeklődés mértéke alacsony szintű, és mindez alapvetően befolyásolja a szervezet egységei közötti kommunikációt.

A szórások viszonylag magas értékei jelzik, hogy a szervezet dolgozói egy része kevésbé érez gátló tényezőket az egységek kommunikációjában, míg más ezt sűrűbben tapasztalja.

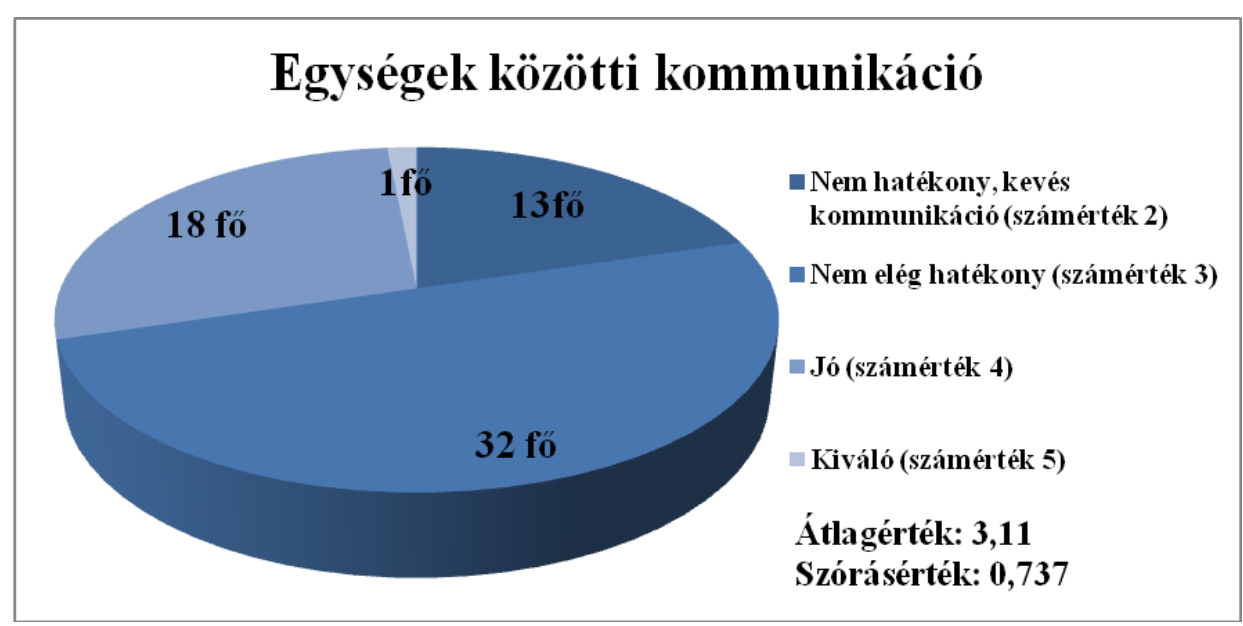

4. ábra: A szervezet egységei közötti kommunikáció értékelése

A minta a szervezet egységei közötti kommunikációt csak 3,11-os áltag értékű, 0,737-es szórás mellet, ami jelzést ad arról, hogy a dolgozók szinte egy véleményen vannak e kérdés tekintetében. 
A válaszadók 50\%-a, 32 fő (4. ábra) csak közepes mértékben elégedett az egységek közötti kommunikációval. A kapott adatokra magyarázatot adhat, hogy ha egy szervezet egyes egységei térben távol helyezkednek el egymástól (mint a vizsgált intézmény esetén is), akkor belső kommunikációjuk nehezebben hangolható össze. Romlik annak hatékonysága, kevesebb a személyes érintkezési lehetőség, ami a szervezet egészére kifejti negatív hatását. Ugyanakkor a vizsgált intézményben nincs is olyan személy, akinek a feladata a kommunikáció szervezése lenne, ami véleményem szerint egy ilyen méretű és felépítésű szervezet esetén mindenképp negatívan befolyásolja a belső kommunikáció működését. Az egyes egységek dolgozói más részlegek alkalmazottait feltételezhetően nem ismerik megfelelőképp az eredményes közös munkavégzéshez, ami akár kollektív projektek, vagy különböző problémák megoldásánál hátrányt jelenthet, nem is beszélve arról, hogy feltételezhetően a szervezeti kultúra, a közös szervezeti értékek sem jelennek meg egyformán az egyén szintjén. Az egységes szervezeti kultúra létezése nélkül pedig nem lehet beszélni jól működő szervezeti belső kommunikációról sem.

\subsubsection{Térbeli távolság és a személyes kontaktus}

Az elvégzett kutatás szerint a legszívesebben alkalmazott kommunikációs csatorna az e-mail (a válaszadók 92,19\%-a jelölte meg) mellett a személyes beszélgetés (90,63\%) volt (5. ábra).

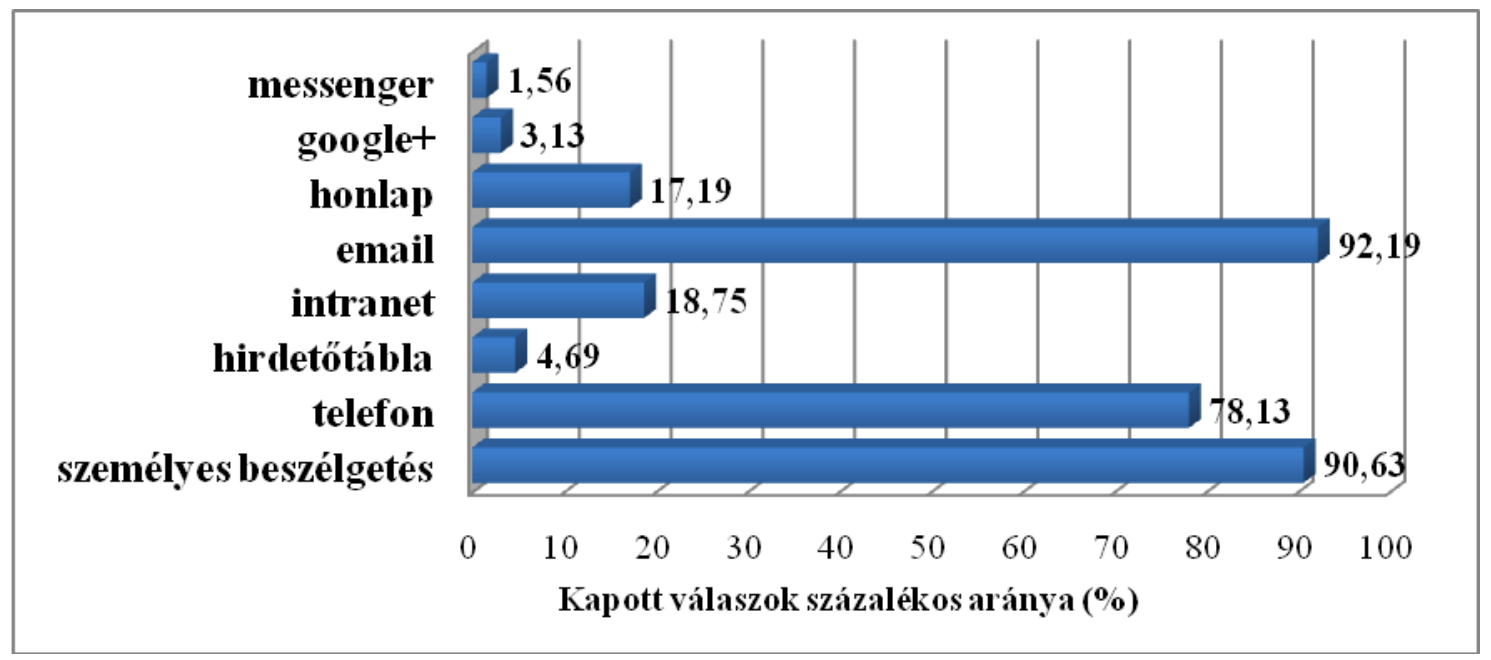

5. ábra: A kommunikációs csatornák használatának kedveltsége a válaszok alapján

A szemtől szembeni kommunikáció fontosságát igazolva, annak hiánya a gátló tényezők között is kiemelkedik (3,16-os átlagértéket kaptam a nincs személyes kontaktus tényezőre, 4. táblázat), ami egyértelműen bizonyítja, hogy fontos a szemtől szembeni információcsere az alkalmazottak számára. A személyes kontaktus hiányát összehasonlítva és egységekre vetítve a szervezeti egységek közötti térbeli távolsággal (6. ábra), mint kommunikációs akadállyal kijelenthető, hogy a jelen esetben kisebb és elszigeteltebb, a többi egységtől távolabb elhelyezkedő részek felé haladva a nagyok felől mind a két tényező esetén növekvő tendenciát mutató átlagértékeket kaptunk. Ez egyértelműen jelzi, hogy a nagy térbeli távolság a személyes kontaktus csökkenését okozza a szervezet részei között, és ezzel mind a két tényezőt a belső kommunikáció kiemelt gátlójaként jelölték meg a legkisebb egység dolgozói, ami alighanem visszahat az egységek közötti kommunikáció minőségére is. 


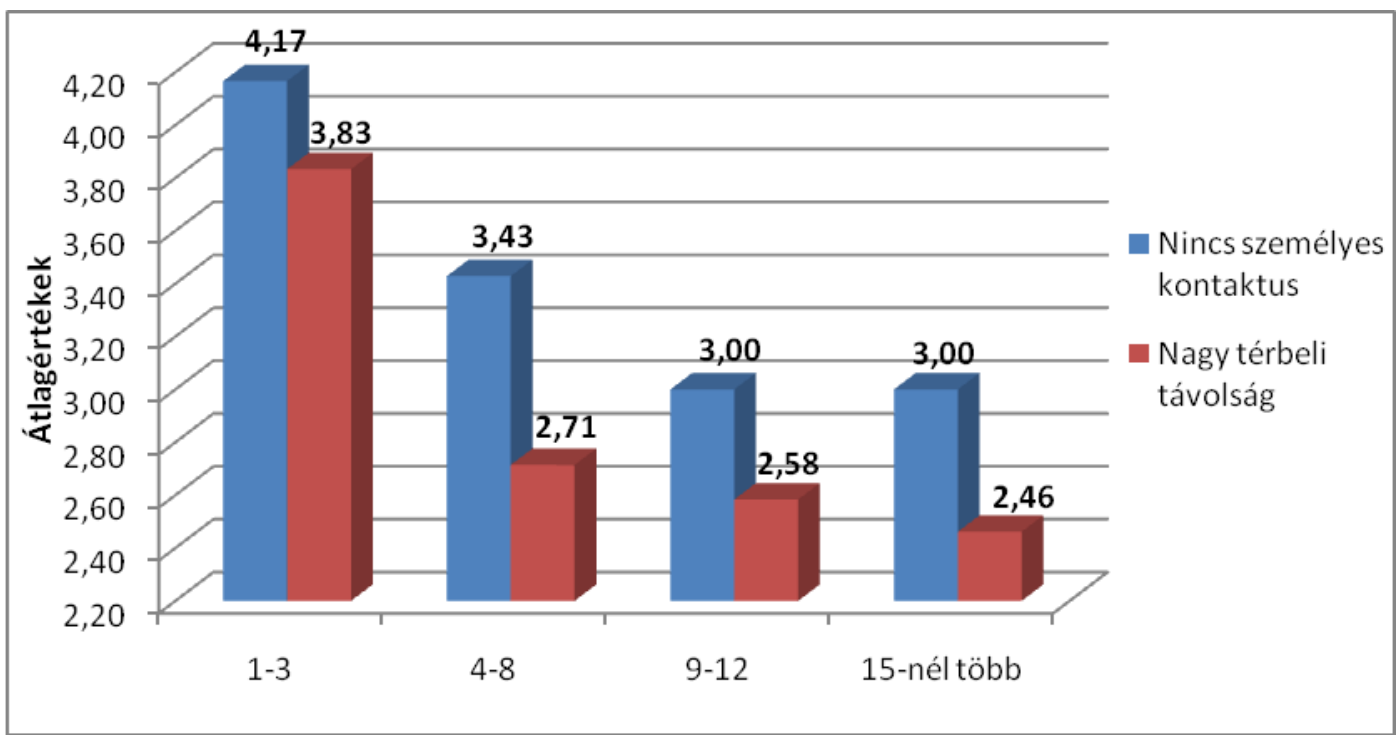

6. ábra: Térbeli távolság és a személyes kontaktus hiányának összefüggése szervezeti egységenkénti bontásban

Kézenfekvő lenne a távolabb elhelyezkedő szervezeti egységek számára, hogy a személyes kontaktus hiányát a modern technika eszközeinek felhasználásával küszöböljék ki, amihez megfelelő technikai felszereltségre van szüksége a vizsgált intézménynek, amely igényt megerősíti, hogy a jól működő technikai eszközöket a válaszadók 68,75\% tartotta fontosnak a kiegyensúlyozott kommunikációhoz. A technika színvonalának pillanatnyi állapotára ellenben csak átlagosan csak 3,36-os értéket kaptunk, 0,897-es szórásérték mellett, ami jelzi, hogy a dolgozók csak közepes mértékben elégedettek a kommunikációs infrastruktúrával.

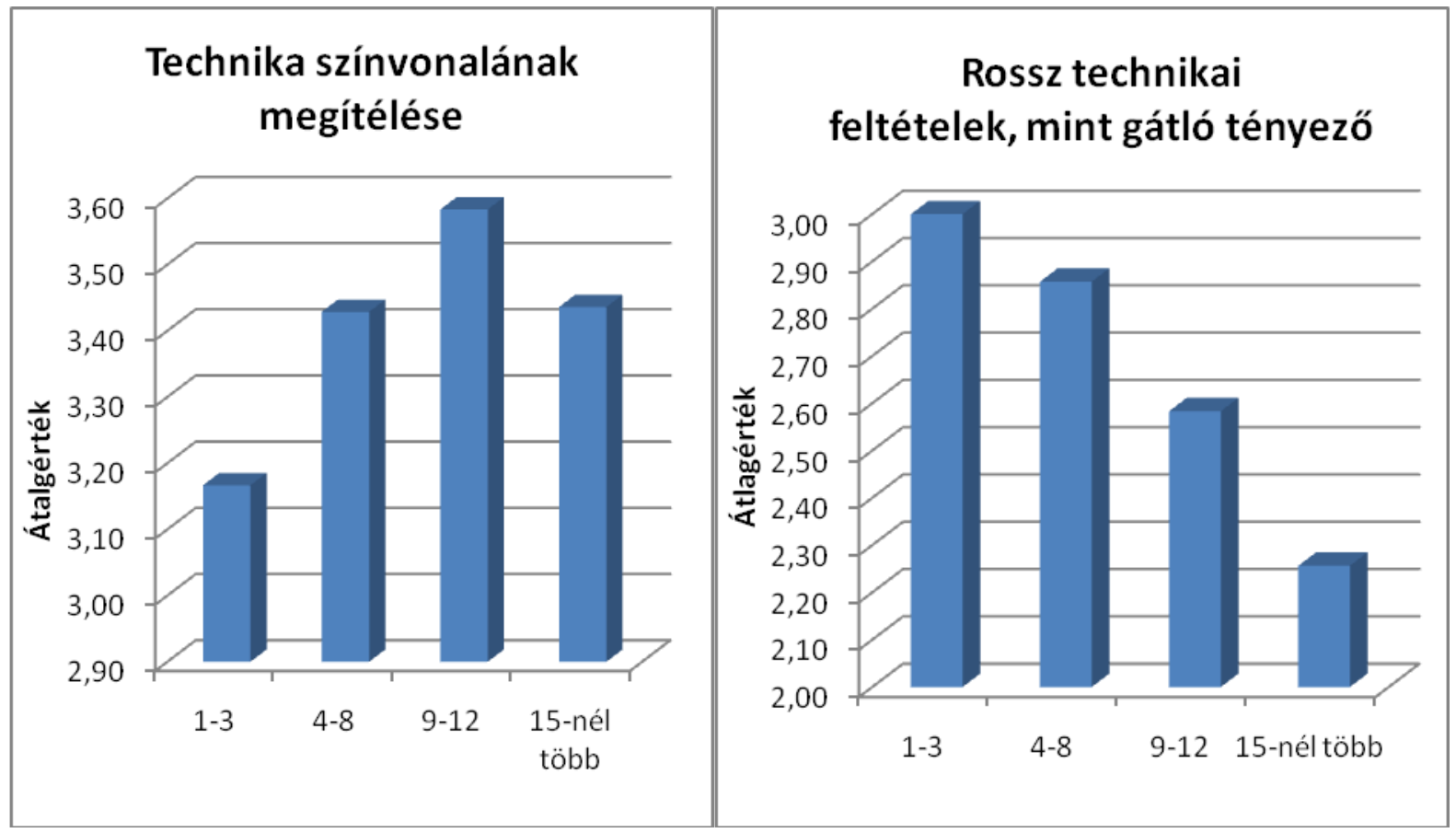

7. ábra: Az egyes egységek véleménye a technika színvonaláról és a rossz technikai feltétel kommunikációt gátló hatásáról 
A technikai eszközök kérdését vizsgálva további összefüggés állapítható meg (7. ábra) a térbeli távolság okozta „elszigeteltség” miatt. A technika színvonalát elemezve láthatóvá vált, hogy a távolabb elhelyezkedő egységek ítélik annak jelenlegi állapotát kevésbé jónak, és ezzel párhuzamosan, mint gátló tényezőt fontosabbnak tartják, mint az intézmény többi része.

\section{Összegzés}

Az elvégzett kutatásunk alapján megállapítható hogy a felmérésben résztvevő intézmény alkalmazottai fontosnak tartják a belső kommunikáció hatását a vizsgált tényezőkre, ezzel is igazolva a szakirodalmat, hogy a hosszú távú sikeresség elérésében az alkalmazottakkal folytatott hatékony kommunikáció fontos szerepet tölt be és a szervezeti belső kommunikáció alapjaiban határozza meg a szervezetben dolgozók kapcsolatait, a vezetés döntési mechanizmusát, a szervezeti kultúrát, és a szervezeti működést. A legkisebb szervezeti egységek tartották az intern kommunikációt szinte minden vizsgált tényező esetén a legjelentősebbnek.

A vezetői döntéshozatal belső kommunikáció általi befolyásolásában szignifikáns különbség rajzolódott ki az kevesebb dolgozóval (1-3, 4-8) működő szervezeti egységek javára a nagyobbakhoz viszonyítva, ami feltételezi, hogy az alkalmazottak a kis egységekben nagyobb hatást fejthetnek ki a döntéshozatalra. Ezt megerősítette az is, hogy a kis részlegekben a vezető és beosztott között erősebb, bizalmasabb viszony áll fent a kutatás szerint. Mindez pedig eredményezi, hogy a kevesebb dolgozóval rendelkező szervezeti egységek vezető-beosztotti kapcsolat harmóniája kiegyensúlyozottabb, amely hozzájárul a vezetői döntések gördülékenyebb elfogadásához is.

A térbeli távolság valóban negatív hatást fejt ki a szervezeti belső kommunikációra, ugyanis igazolódott, hogy csökkenti a személyességet. Fontos továbbá megállapítani, hogy e tényezőt a személyes kontaktus hiányának kontextusában vizsgálva egyértelműen kijelenthető, hogy a térben távolabb elhelyezkedő szervezeti részek számára fontosabb a szemtől szembeni kommunikáció, még a modern technikai eszközök mellett is. Ugyanakkor az is világosan láthatóvá vált, hogy a szervezetben rendelkezésre álló technikai eszközök nem megfelelősége is a térben távolabb elhelyezkedő egységek számára jelent számottevő kommunikációs akadályt.

A kapott részeredmények tükrében a vizsgált intézménynek mindenképpen szükséges lenne a belső kommunikációját tudatosan szervezni, kommunikációs munkakört kialakítani, valamint a hatékonyabb szervezeti együttműködés érdekében felül kellene vizsgálni a vezetők és beosztottak közötti viszonyt és a rendelkezésre álló technikai eszközök megfelelőségét.

\section{Irodalomjegyzék}

1. Bakacsi, Gy. (2002): Szervezeti magatartás és vezetés. KJK-KERSZÖV, Budapest.ISBN 963 2244966

2. Borgulya, I. (2010): Kommunikációmenedzsment a vállalati értékteremtésben. Akadémiai Kiadó, Budapest. ISBN 9789630588362 
3. Dajnoki, K. (2003): A vezetés és a kommunikáció összefüggései In: Agrártudományi közlemények = Acta Agraria Debreceniensis, 10. pp. 248-255. ISSN 1587-1282

4. Fóris, Á. (2008): Kutatásról nyelvészeknek. Bevezetés a tudományos kutatás módszertanába. Nemzeti Tankönyvkiadó, Budapest. ISBN 978-963-19-6323-6

5. Higham, T. M. (1966): Alapvető pszichológiai tényezők a kommunikáció terén. In: Sutermeister, R.A.: Ember és termelékenység. Közgazdasági és Jogi Kiadó, Budapest

6. Johnson, A. R., Kast, F. E., Rosenzweig, J. E. (1971): In: Kindler J., Kiss I. (szerk.): Rendszerelmélet: válogatott tanulmányok. Közgazdasági és Jogi Kvk., Budapest. pp. 221409.

7. Kabai, I. (2009): A diplomás pályakövető rendszer kutatásainak módszertana. L'Harmattan, Budapest. ISBN 9789632363554

8. Karoliny, M., Poór, J. szerk. (2010): Emberi erőforrás menedzsment kézikönyv. Complex, Budapest. 9789632951089

9. Klein, S. (2001): Vezetés- és szervezetpszichológia. SHL Hungary, Budapest. ISBN 96300 70081

10. Mikulás, G. (1999): Menedzsment: bevezetés 7 vezetői teszttel, 222 információs és könyvtári példával. „Szabolcs-Szatmár-Bereg Megyei Könyvtárak” Egyesülés, Nyíregyháza. ISBN: 9630372886

11. Mintzberg, Henry (1975): The manager's job: folklore and fact. In: Harvard Business Review. 53/4.pp. 49-61.

12. Mónus, Á. (2001): Public relations: a bizalomépítés művészete. SHL Hungary, Budapest. ISBN 9630063948

13. Nagy, J. (1974): A vállalati rendszerszervezés elmélete. Statisztikai Kiadó Vállalat, Budapest.

14. Nagypál, M. (2009): A munka minőségét rontja a rossz kommunikáció [elektronikus dokumentum] http://www.hrportal.hu/hr/a-munka-minoseget-rontja-a-rosszkommunikacio-20091014.htmlLetöltés időpontja: 2014.09.10.20:13

15. Nyárádi, G. (2002): A belső kommunikáció szerepe közintézményekben. In: Múzeumi Közlemények 1/1 pp. 15-19. ISSN 1589-4959

16. Papp, T. (2005): Kommunikáció cégen belül. In: Cégvezetés 13/3. pp.37-42. ISSN 1217$615 \mathrm{X}$

17. Roebuck, C. (2000): Hatékony kommunikáció. Scolar, Budapest. ISBN 9639193437

18. Rosengren, K. E. (2004): Kommunikáció. Typotex, Budapest. ISBN 9639326984

19. Semeginé Tariszka, É. (2009): Szervezeti belső kommunikáció. In: Economica 2/2. pp.103-112. ISSN1585-6216 
International Journal of Engineering and Management Sciences (IJEMS) Vol.1. (2016). No. 2.

DOI: 10.21791/IJEMS.2016.2.21.

20. Semeginé Tariszka, É.(2013): Informális szervezetek. In: Tudásmenedzsment. 14/2. pp. 24-31.

21. Tracy, B. (2014): Motiváció. Trivium Kiadó, Budapest. ISBN 9786155334085 